\title{
First report of Monticellius indicum Mehra, 1939 (Digenea: Spirorchiidae) infecting Chelonia mydas Linnaeus, 1758 (Testudines: Chelonidae) from Brazil
}

\author{
Werneck, MR. ${ }^{\mathrm{a} *}$, Gallo, BMG. ${ }^{\mathrm{a}}$ and da Silva, RJ. ${ }^{\mathrm{b}}$ \\ aFundação Pró-Tamar, Rua Antônio Athanázio da Silva, 273, Itaguá, CEP 11680-000, Ubatuba, SP, Brazil

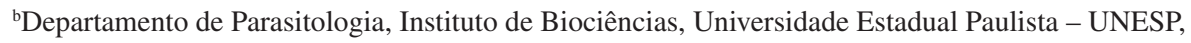 \\ Distrito de Rubião Júnior, s/n, CEP: 18618-000 Botucatu, SP, Brazil \\ *e-mail: max@tamar.org.br \\ Received February 18, 2008 - Accepted April 11, 2008 - Distributed May 31, 2008
}

(With 1 figure)

The family Spirorchiidae includes trematodes of freshwater and marine chelonian blood vessels. Up to now, Learedius learedi Price, 1934 has been the only species of this family described in Brazil (Werneck et al., 2006). The present study reports for the first time the occurrence of Monticellius indicum Mehra, 1939 in Brazilian waters.

Specimens of $M$. indicum were collected from the heart of two young Chelonia mydas Linnaeus, 1758 found in Ubatuba, on the North Coastline region of São Paulo State, Brazil. One turtle was found in June, 2006 on Lázaro beach (23 30' $11,76^{\prime}$ " $\mathrm{S}$ and $\left.45^{\circ} 08^{\prime} 8,76^{\prime \prime} \mathrm{W}\right)$, had $40.0 \mathrm{~cm}$ curved carapace length and weighed $5.5 \mathrm{~kg}$. The other was found on Flamengo beach ( $23^{\circ} 30^{\prime} 46,74$ " S and $45^{\circ} 06^{\prime} 38,44^{\prime \prime}$ W) in June, 2007, had $40.0 \mathrm{~cm}$ curved carapace length and weighed $6.0 \mathrm{~kg}$. The firs turtle was found floating near the coast and died at the TamarICMBio Project Marine Sea Turtles Rehabilitation Center and the other turtle was found dead after contact with a fishing net.

The circulatory system was examined according to the method described by Snyder and Clopton (2005) and modified by Werneck et al. (2006). The helminths $(n=3)$ were fixed in AFA (Alcohol-Formalin-Acetic Acid) solution, stained with chloridric carmine and analyzed on a computerized system for image analysis (QWin Lite 3.1 - Leica). Morphometrical values (in micrometres) are shown as mean and range (minimum - maximum). The helminths were deposited in the Helminthological Collection of the Biosciences Institute, Unesp, Botucatu (CHIBB, numbers 2008 and 2528).

Between 2005 and 2008, 239 C. mydas specimens were necropsied at the Tamar-ICMBio Project Marine Sea Turtles Rehabilitation Center and $M$. indicum was found in only two hosts (prevalence $=0.83 \%$ ).

The main characteristics of the M. indicum (Figure 1) specimens were as follows: small, narrow and elongated body, 4535.7 (3666-5646.6) long by 390.1 (358.7-432.7) width; oral sucker terminal, 132.2 (86.3-185.4) long by 172.5 (144.5-194.7) width; esophagus 418.8 (338-513.1) long by 70.8 (36.3-94.4) width; ventral sucker placed between caecal bifurcation and testis, 239.3 (164-318.4) long by 165.1 (131-194.4) width; five tes- tis in the middle of the body, 179.8 (110.9-227) long by 187.5 (134.7-276.1) width; cirrus pouch is long and narrow, 713.4 (517.8-868.8) long by 76.4 (66.8-94.1) width; ovary lobed and large, 474.3 (450-517.7) long by 162.8 (122.8-220.9); vitellaria composed of small follicles, spread from caecal bifurcation to posterior region of the ovary, intra and extracecal, except in the pre-testicular region, where it is just intercecal; eggs were not observed.

Parasite morphological data were similar to the original description of the species except for body length and esophagus length and width. In our study, these measurements were higher than those cited by Mehra (1939). That author studied only one specimen, whereas three helminths were analyzed in the present study. These results are important for the knowledge of the morphometrical variation of the species.

Only two reports on $M$. indicum are available in the literature. Mehra (1939) described the species infecting one specimen of $C$. mydas from India. Later, Santoro et al. (2006) reported a prevalence of $12.5 \%$ of this para-

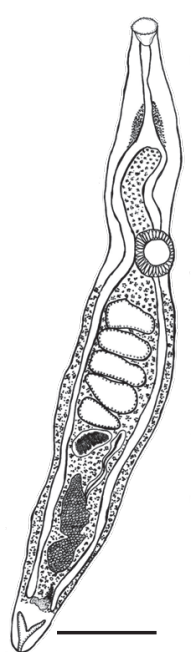

Figure 1. Monticellius indicum Mehra, 1939 (Digenea: Spirorchiidae) specimen collected from a Chelonia mydas Linnaeus, 1758 (Testudines: Chelonidae) on the Brazilian coast. (bar $=0.5 \mathrm{~mm})$. 
site in 40 adult females of C. mydas from Costa Rica, with an infection intensity of $1.6 \pm 0.6$ parasites. These results show that $M$. indicum is rarely reported in chelonians and that its prevalence seems to be usually low, as observed in the present study.

This is the first report of $M$. indicum in sea turtles on the Brazilian coast representing important information on the helminth fauna of $C$. mydas.

Acknowledgments - Projeto TAMAR is affiliated to ICMBio, co-managed by the Fundação Pró-TAMAR, and officially sponsored by PETROBRAS. We would like to thank the Fundação de Amparo à Pesquisa do Estado de São Paulo FAPESP (Proc. 07/59504-7) for the financial support. The authors wish to express their thanks to Paula Baldassin, Cecília Baptistotte and Verônica Gama for critical reading and suggestions to improve the manuscript.

\section{References}

MEHRA, HR., 1939. New blood flukes of the family Spirorchiidae Stunkard (Trematoda) from the marine turtle
Chelone mydas of the Arabian Sea with observations on the synonymity of certain genera and classification of the family. Proc. Natl. Acad. Sci. India, vol. 9, no. 4, p. 155-167.

SANTORO, M., GREINER, EC., MORALES, JA. and RODRÍGUEZ-ORTÍZ, B., 2006. Digenetic trematode community in nesting green sea turtles (Chelonia mydas) from Tortuguero Nacional Park, Costa Rica. J. Parasitol., vol. 92, no. 6 , p. 1202-1206.

SNYDER, S. and CLOPTON, R., 2005. New methods for the collection and preservation of spirorchiid trematodes and Polystomatid manogeneus from turtles. Comp. Parasitol., vol. 72 , no. 1, p. 102-107.

WERNECK, MR., BECKER, JH., GALLO, BG. and SILVA, R.J., 2006. Learedius learedi Price 1934 (Digenea, Spirorchiidae) in Chelonia mydas Linnaeus 1758 (Testudines, Chelonidae) in Brazil: case report. Arq. Bras. Med. Vet. Zootec., vol. 58 , no. 4 , p. $550-555$. 